\title{
ELIMINATION DYNAMICS OF NICKEL, ADMINISTERED BY A SINGLE INTRAPERITONEAL INJECTION, IN COMMON CARP, CYPRINUS CARPIO L.
}

\section{Ewa BRUCKA-JASTRZĘBSKA ${ }^{1}$, Mikołaj PROTASOWICKI ${ }^{2}$}

\author{
${ }^{1}$ Division and Chair of Physiology, University of Szczecin, Poland \\ ${ }^{2}$ Division and Chair of Toxicology, Agricultural University of Szczecin, Poland
}
Brucka-Jastrzębska E., Protasowicki M., 2004. Elimination dynamics of nickel, administered by a single intraperitoneal injection, in common carp, Cyprinus carpio L. Acta Ichthyol. Piscat. 34 (2): 181-192.

Background. Some heavy metals are essential to living organisms but their excess can disturb the homeostasis of an animal. The aim of the study was to assess effects of nickel compounds on carp, Cyprinus carpio L., and to follow the toxicodynamics of this metal elimination from intoxicated fish once they were transferred to a clean ambience.

Material and methods. Individuals of carp, Cyprinus carpio L. were given a single intraperitoneal injection of a sub-lethal nickel nitrate dose $\left(60 \mu \mathrm{g} \mathrm{Ni} \cdot \mathrm{kg}^{-1}\right.$ body weight) to assess their detoxification potential following transfer to uncontaminated habitat. The 60-day experiment was divided into 8 stages during which various organs and tissues of the fish (liver, kidneys, skin, gills, alimentary tract, muscles) were examined and subjected to assays for nickel contents at pre-set times. Nickel was determined with inductively coupling plasma atomic emission spectrometry (ICP-AES) in a JY-24 Jobin Yvon apparatus after wet digestion in concentrated $\mathrm{HNO}_{3}$ in CEM MDS 2000 microwave oven. Results. The fish intoxicated with $\mathrm{Ni}$ shown some behavioural changes; they were sluggish and stay near the bottom of a tank, their responses to light and sound were much slower than those of the control fish. The nickel level was observed to change with time: after initial nickel accumulation in the tissues, the metal was eliminated. The experiment highlighted changes in the intoxicated carp system during the process of detoxification. The highest biological half-life $\left(t_{1 / 2}\right)$ of nickel was recorded in alimentary tract (10 days), the lowest being typical of the liver (1.8 days).

Conclusion. During detoxification, nickel was observed to be redistributed among the examined organs. Its elimination rate was depended on organ and varied from 0.003 to $0.008 \mu \mathrm{g} \cdot \mathrm{day}^{-1}$. A long-term effect of sub-lethal intoxication was an about $5 \%$ reduction of the fish body weight. This study has been financially supported by the State Committee for Scientific Research (KBN) (grant No. 3 PO4E 030 22).

Key words: fish intoxication, carp, Cyprinus carpio, nickel, elimination, dynamics.

* Correspondence: Dr Ewa Brucka-Jastrzębska, Katedra Fizjologii, Uniwersytet Szczeciński, al. Piastów 40b, 71-065 Szczecin, Poland, e-mail: eva99@op.pl 


\section{INTRODUCTION}

Pollutants affecting the natural environment include certain chemical elements released into ecosystems as a result of multifaceted activity of humans. Their presence changes individual development of both plants and animals. Biological effects of disturbed chemical homeostasis appear in the environment much earlier, before symptoms and biochemical changes appear in individual organisms. Environmental pollution and the resultant changes are related to the constant transport and exchange of materials. Depending on their properties, pollutants and contaminants of various kinds differ in the pathways and intensity of their transfer to the soil, water, and air, and thence to plant and animal bodies. All pollutants affect the health state of organisms as a result of direct or indirect effects, the latter ensuing through accumulation of toxic compounds ingested with food. The fish are directly associated with water; they are an important component of human diet. For humans, they can be a source of xenobiotics that adversely affect human life functions (Żmudzki and Szkoda 1996). Sobecka (2001) proved disorders in the iron level in the organs and tissues of wells catfish, Silurus glanis L. caused by nickel. Xenobiotics are eliminated from the body unchanged or as polar metabolic products. Depending of physicochemicals properties of a toxin, it is eliminated with urea, faeces, through the respiratory system or skin (Murray et al. 1999).

The aim of the study described in this paper was to assess effects of nickel compounds on common carp, Cyprinus carpio L. exposed to nickel via an intraperitoneal injection, and to follow the toxicodynamics of nickel elimination from intoxicated fish once they were transferred to a clean ambience. Specifically, dynamics of absorption, transfer, and - especially-elimination of the toxic substance after a single intraperitoneal injection were followed and changes in the fish body during those processes were observed.

\section{MATERIAL AND METHODS}

The study involved individuals of common carp, Cyprinus carpio L. obtained from the experimental station of the Agricultural University of Szczecin. A total of 120 individuals of $17.5-20.2 \mathrm{~cm}$ body length and $88.3-38.7 \mathrm{~g}$ body weight were used. At the onset and on termination of the experiment, the carp were 3- and 5.5 month-old, respectively. After their delivery to the laboratory, the fish were placed in six 1201 aerated tanks, 20 individuals in each; the tanks were filled with tap water. To dechlorinate the tank water and to bring its temperature to the ambient level, the tanks were filled and aerated for 48 hours prior to fish release. Under such conditions, the fish were acclimated for 14 days. The tank water was changed daily; during acclimation, the fish were in good condition. The carp were fed the Aller pelleted feed mix containing $37 \%$ protein and 12 $\%$ fat; the feed was identical to that applied in culture at the experimental station. The daily food amount was $3.4 \pm 0.2 \mathrm{~g}$ per fish. Throughout the experiment, the tank water 
temperature oscillated around $21 \pm 2^{\circ} \mathrm{C}$; the dissolved oxygen content, $\mathrm{pH}$, and hardness of the water were 8.0-9.0 $\mathrm{mg} \mathrm{O}_{2} \cdot \mathrm{l}^{-1}, 7.0-7.5$, and $10.71 \mathrm{mval} \cdot \mathrm{l}^{-1}$, respectively.

The experiment involved a single intraperitoneal injection of nickel nitrate. Each fish was randomly assigned to one of three groups of 40 individuals, and next each group was subdivided into two sub-groups of 20 individuals per tank. The first group was a control and consisted of individuals, which were not subject to any treatment; this was the so-called physiological group $\left(\mathrm{W}_{\mathrm{Fiz}}\right)$. The second group $\left(\mathrm{W}_{\mathrm{H}_{2} \mathrm{O}}\right)$ consisted of fish that received a single intraperitoneal injection of $1 \mathrm{ml}$ deionised water. The fish in the third group $\left(\mathrm{W}_{\mathrm{Cd}}\right)$ were given a single injection of aqueous nickel $\left(\mathrm{Ni}^{2+}\right)$ solution in the form of nickel (II) nitrate (V), applied at a dose of $60 \mu \mathrm{g} \cdot \mathrm{kg}^{-1}$ body weight.

The experiment took 60 days after the injection. The water used for injection and for preparing the nickel nitrate solution to be injected was deionised and UV sterilised in an EASY Pure UV apparatus (Barnstead). Random samples of 5 fish each were collected from each group prior to the injection (hour 0 ) and 6 hours post injection as well as after 1, 3, 7, 14, 30, and 60 days.

Chemical assays were performed on samples of gills, anterior and mid-posterior parts of the alimentary tract, liver, kidneys, skin, and muscles, which were dissected and kept frozen at $-20^{\circ} \mathrm{C}$ until analysed. Muscles samples were taken from dorsum.

Nickel effects on carp behaviour were observed throughout the experiment. External morphological changes in those individuals selected for assays were recorded; during necropsy, the appearance and consistence of gills and viscera was described as well.

Prior to the actual assay, 1-g tissue samples (weighed to $0.001 \mathrm{~g}$ ) were mineralised wet in $3 \mathrm{ml}$ concentrated $\mathrm{HNO}_{3}$ in a CEM MDS 2000 microwave oven. The solution obtained was quantitatively transferred to polyethylene bottles and brought to $30 \mathrm{~g}$ with deionised water. The samples prepared this way were assayed for Ni. Using inductively coupling plasma atomic emission spectrometry (ICP-AES) in a JY-24 Jobin Yvon apparatus.

The tissue nickel content in $\mu \mathrm{g} \cdot \mathrm{g}^{-1}$ wet weight $\left(\mu \mathrm{g} \cdot \mathrm{g}^{-1} \mathrm{ww}\right)$ was calculated from a relevant calibration curve and data were corrected for procedural blank.

The data obtained were used in toxicokinetic calculations utilising formulae given by Grabowski (2003). The following toxicokinetic and toxicodynamic parameters were calculated: area under curve (AUC), area under first moment curve (AUMC), mean retention time (MRT), distribution coefficient $\left(\mathrm{V}_{\mathrm{d}}\right)$, biological half-life $\left(\mathrm{t}_{1 / 2}\right)$, organ clearance $(\mathrm{Cl})$, elimination rate constant $(\beta)$, initial concentration, recorded at the start of the experiment $\left(\mathrm{C}_{\mathrm{o}}\right)$, maximum concentration $\left(\mathrm{C}_{\max }\right)$, time of maximum concentration $\left(\mathrm{t}_{\max }\right)$, last recorded concentration $\left(\mathrm{C}_{\text {last }}\right)$, and the time of last sampling (termination of the experiment) (tlast).

The results were subjected to statistical treatment with the aid of Statistica 6.0 software. The data were tested for normality of distribution with the 
Kolmogorov-Smirnov test and were subject to one- and multi-way analysis of variance (ANOVA, Scheffé's test) at the significance level of $P=0.05$.

\section{RESULTS}

The control fish $\left(\mathrm{W}_{\mathrm{Fiz}}\right)$ and those injected deionised water $\left(\mathrm{W}_{\mathrm{H}_{2} \mathrm{O}}\right)$ showed no changes in behaviour and external appearance, and neither did their food consumption change. On the other hand, some changes were observed in the nickel-intoxicated fish, and which persisted until the termination of the experiment. The nickel-intoxicated fish were sluggish and tended to stay near the bottom of a tank, while their responses to light and sound were much slower than those of the control fish and the fish injected with deionised water. The intoxicated fish lost appetite after 7 days. Until day 30 , they clearly differed in the amount of food consumed when compared to the control but difference diminished with time. As a result, no difference could be observed after 30 days of the experiment. The fish receiving both types of injection developed clearly visible changes at the injection site. As of day 7 of the experiment, some nickel-injected fish developed ecchymoses on the fins and gills. Until day 7, the gill lamellae of the nickel-injected fish were clearly much lighter in colour. The necropsy revealed ecchymoses on the kidneys in $24 \mathrm{~h}$ post injection, liver hyperaemia being observed after 3 days.

Nickel contents were observed to increase in the organs (muscle, gills, kidney, and skin) of the nickel-intoxicated fish at the initial stage of the experiment but not for control or deionised water-injected fish (Fig. 1).

As of the moment of injection, nickel was absorbed by, distributed among, and accumulated in various fish organs. In all of them, the nickel content was observed to increase within the initial 24 hours post injection, the return to the equilibrium ensuing thereafter. Muscles were the exception as the muscle nickel content peaked after as long as 3 days (Fig. 1).

Nickel contents were observed to increase in the organs (liver, mid-posterior part of alimentary tract, anterior part of alimentary tract) of the nickel-intoxicated fish at the initial stage of the experiment but not for control or deionised water-injected fish (Fig. 2).

The maximum, initial, and final nickel contents in all the organs are shown in Table 1.

As shown by the data, once the nickel concentration peaked, redistribution and elimination began. As a result, after 60 days from the start of the experiment, the nickel contents in all the organs dropped to the values close to those recorded prior to injection. 

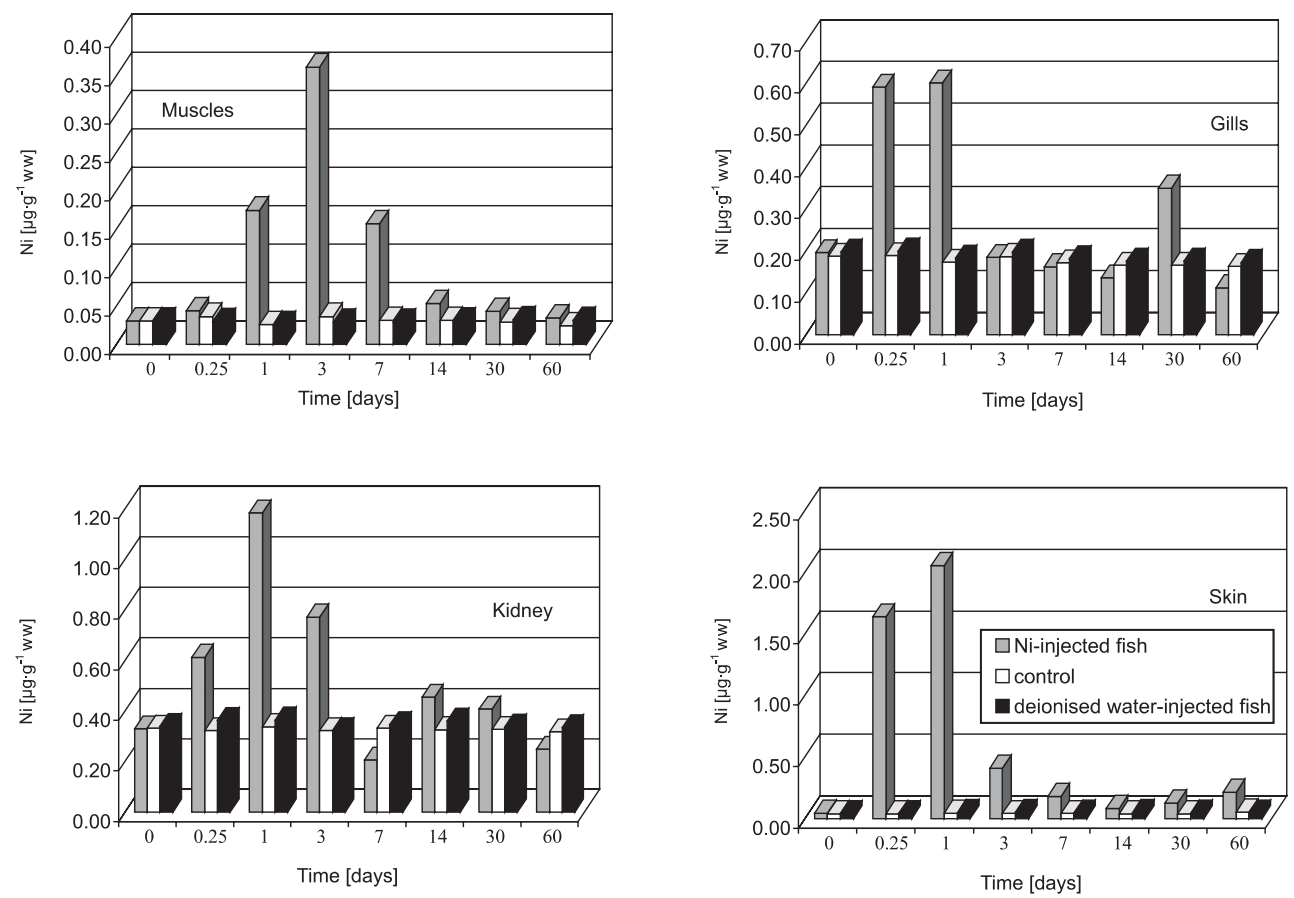

Fig. 1. Changes in nickel contents $\left[\mu \mathrm{g} \cdot \mathrm{g}^{-1}\right.$ wet weight] during detoxification in the organs examined

It is interesting to follow nickel contents in the gills where the metal was absorbed during the initial 24 hours and accumulated to the maximum level $\left(\mathrm{C}_{\max }=0.602\right.$ $\mu \mathrm{g} \cdot \mathrm{g}^{-1}$ ww) (Fig. 1). Subsequently, distribution within the organ and elimination was taking place until day 14 post-injection. The gill nickel content dropped to the level recorded on the onset of the experiment $\left(\mathrm{C}_{0}=0.194 \mu \mathrm{g} \cdot \mathrm{g}^{-1} \mathrm{ww}\right)$. As of day 14 , nickel was transported to the gills from other organs, as a result of which its content increased again. The increase took until day 30 of the experiment when elimination began (Fig. 1). On day 60 , the gill nickel content was very low $\left(C_{\text {last }}=0.112 \mu \mathrm{g} \cdot \mathrm{g}^{-1} \mathrm{ww}\right)$, evidencing total elimination of the nickel injected.

Peritoneal injection of deionised water produced no changes in nickel content in the fish organs, as evidenced by the lack of statistically significant differences. No differences in nickel content were observed between the control and deionised waterinjected fish, either. Nickel contents in the two groups were similar and did not undergo any major changes during the 60 days of the experiment (Fig. 1). 

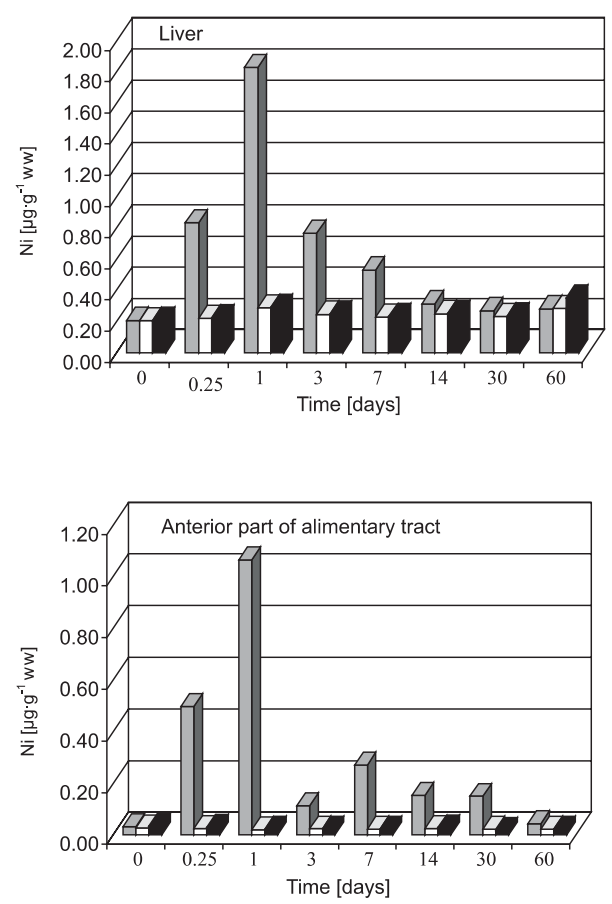

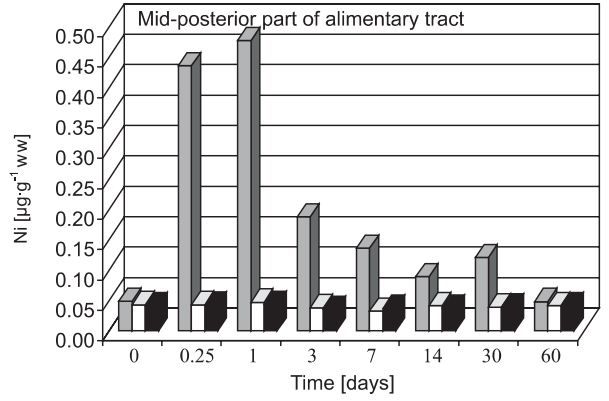

Ni-injected fish

$\square$ control

deionised water-injected fish

Fig. 2. Changes in nickel contents $\left[\mu \mathrm{g} \cdot \mathrm{g}^{-1}\right.$ wet weight] during detoxification in the organs examined

Table 1

Initial, maximum, and final nickel contents $\left[\mu \mathrm{g} \cdot \mathrm{g}^{-1} \mathrm{ww}\right]$ in carp organs after a single intraperitoneal injection

\begin{tabular}{|c|c|c|c|c|c|}
\hline Organ & $\begin{array}{l}\mathrm{C}_{0}\left[\mathrm{t}_{0}\right] \\
\bar{x} \pm s\end{array}$ & $\begin{array}{l}\mathrm{C}_{\max } \\
\bar{x} \pm s\end{array}$ & $\begin{array}{c}\mathrm{t}_{\max } \\
\text { [days] }\end{array}$ & $\begin{array}{c}\mathrm{C}_{\text {last }} \\
\bar{x} \pm s\end{array}$ & $\begin{array}{c}\mathrm{t}_{\text {last }} \\
\text { [days] }\end{array}$ \\
\hline Kidneys & $0.328 \pm 0.038$ & $1.183 \pm 0.096$ & 1 & $0.248 \pm 0.021$ & 60 \\
\hline Liver & $0.205 \pm 0.022$ & $1.829 \pm 0.090$ & 1 & $0.280 \pm 0.031$ & 60 \\
\hline $\mathrm{AAT}$ & $0.031 \pm 0.003$ & $1.064 \pm 0.017$ & 1 & $0.044 \pm 0.007$ & 60 \\
\hline MAT & $0.049 \pm 0.003$ & $0.478 \pm 0.010$ & 1 & $0.048 \pm 0.003$ & 60 \\
\hline Gills & $0.196 \pm 0.024$ & $0.602 \pm 0.042$ & 1 & $0.112 \pm 0.013$ & 60 \\
\hline Muscles & $0.031 \pm 0.003$ & $0.361 \pm 0.029$ & 3 & $0.035 \pm 0.001$ & 60 \\
\hline Skin & $0.042 \pm 0.003$ & $2.052 \pm 0.086$ & 1 & $0.214 \pm 0.020$ & 60 \\
\hline
\end{tabular}

$\bar{x}$, mean; $s$, standard deviation; sample size $\mathrm{n}=5 ; \mathrm{C}_{0}$, initial Ni content; AAT, anterior part of alimentary tract; MAT, mid-posterior part of alimentary tract; $\mathrm{t}_{0}$, start of the experiment; $\mathrm{C}_{\max }$, maximum content; tmax, time of maximum content; $\mathrm{C}_{\text {last }}$, final $\mathrm{Ni}$ content; $\mathrm{t}_{\text {last }}$, termination of the experiment. 
All the toxicokinetic parameters were calculated for the nickel-injected fish (Table 2). In the two control groups, the values of AUC and AUMC were very similar and much lower than those calculated for the nickel-intoxicated fish $\left(\mathrm{W}_{\mathrm{Ni}}\right)$. The mean nickel retention time (MRT) in the intoxicated fish organs was lower than in the control groups (Table 2).

Table 2

Toxicokinetic parameters revealed by organs of carp subjected to a single intraperitoneal nickel injection

\begin{tabular}{lccccccc} 
Parameter & $\mathrm{K}$ & $\mathrm{L}$ & $\mathrm{AAT}$ & $\mathrm{MAT}$ & $\mathrm{G}$ & $\mathrm{M}$ & $\mathrm{S}$ \\
\hline AUC $\left[\mu \mathrm{g} \cdot \mathrm{day}^{-1} \cdot \mathrm{g}^{-1}\right]$ & 102.61 & 174.79 & 192.50 & 104.02 & 92.64 & 62.41 & 249.17 \\
AUMC & 8750 & 32511 & 80421 & 43764 & 44240 & 17479 & 129555 \\
MRT $[\mathrm{day}]$ & 19.9 & 21.6 & 17.5 & 17.4 & 7.7 & 3.5 & 11.7 \\
$\mathrm{t}_{1 / 2}[\mathrm{day}]$ & 9.9 & 1.8 & 5.8 & 10.0 & 5.5 & 4.8 & 7.8 \\
$\beta\left[\mu \mathrm{g} \cdot \mathrm{day}^{-1}\right]$ & 0.006 & 0.005 & 0.005 & 0.003 & 0.008 & 0.003 & 0.005 \\
$\mathrm{~V}_{\mathrm{d}}[\mu \mathrm{g}]$ & 0.105 & 0.113 & 0.267 & 0.372 & 0.180 & 0.576 & 0.193 \\
$\mathrm{Cl}\left[\mu \mathrm{l} \cdot\right.$ day $\left.^{-1}\right]$ & 0.015 & 0.014 & 0.018 & 0.045 & 0.012 & 0.051 & 0.072 \\
\hline
\end{tabular}

K, kidneys; L, liver; AAT, anterior part of alimentary tract; MAT, mid-posterior part of alimentary tract; $\mathrm{G}$, gills; $\mathrm{M}$, muscles; $\mathrm{S}$, skin.

The data were used as a basis for pharmacokinetic calculations for the nickelintoxicated fish. The highest values of AUC and AUMC were revealed in the skin, anterior part of the alimentary tract, and liver, the lowest values being typical of gills.

Elevated MRT values were recorded in the liver, kidney, anterior and mid-posterior parts of the alimentary tract; the values ranged from 17.40 to 21.66 days. On the other hand, the very short MRT (3.55 days) was displayed by muscles. The highest biological half-life of nickel $\left(\mathrm{t}_{1 / 2}\right)$ was calculated for the mid-posterior part of the alimentary tract (10 days) and kidneys (9.9 days), the lowest value being typical of the liver (1.8 days).

The xenobiotic elimination rate constant $(\beta)$ for the organs under study was found to range within $0.003-0.008 \mu \mathrm{g} \cdot \mathrm{day}^{-1}$. The highest elimination rate was typical of gills $\left(0.008 \mu \mathrm{g} \cdot \mathrm{day}^{-1}\right)$, followed by kidneys $\left(0.006 \mu \mathrm{g} \cdot \mathrm{day}^{-1}\right)$, liver, anterior part of the alimentary tract, and skin $\left(0.005 \mu \mathrm{g} \cdot \mathrm{day}^{-1}\right)$, the lowest rate being shown by the midposterior part of the alimentary tract $\left(0.003 \mu \mathrm{g} \cdot \mathrm{day}^{-1}\right)$.

The coefficient of redistribution of nickel between the organs studied $\left(\mathrm{V}_{\mathrm{d}}\right)$ was calculated as well. High $V_{d}$ values were recorded in muscles $(0.576 \mu \mathrm{g})$ and in the mid-posterior part of the alimentary tract $(0.372 \mu \mathrm{g})$, low values being typical of kidneys $(0.105 \mu \mathrm{g})$. Calculations of the organ clearance $(\mathrm{Cl})$ yielded the highest values in the skin $\left(0.072 \mu \mathrm{l} \cdot \mathrm{day}^{-1}\right)$ and in the mid-posterior part of the alimentary tract $\left(0.045 \mu \mathrm{l} \cdot \mathrm{day}^{-1}\right)$, the lowest values being produced by kidneys $\left(0.015 \mu \mathrm{l} \cdot \mathrm{day}^{-1}\right)$, liver $\left(0.014 \mu \mathrm{l} \cdot\right.$ day $\left.^{-1}\right)$, and gills $\left(0.012 \mu \mathrm{l} \cdot\right.$ day $\left.^{-1}\right)$. 


\section{DISCUSSION}

When analysing intoxication effects, attention should be paid to such a basic concept as biochemical damage which can be defined as a biochemical change or defect that immediately precedes a pathological change or functional disorder. In addition to the target tissue a xenobiotic affects, there are also locations responsible for the processes of absorption, activation, metabolic detoxification, and elimination of xenobiotics. Toxicological diagnostics and toxicokinetics relies also on other types of analyses, e.g. haematological, biochemical, enzymatic, and genetic assays. As they are applied to evaluate, i.e. parameters of a compartment, which is a site of toxicokinetic processes, they are useful in comparisons with control groups. Such analyses supply, among others, a structural assessment of individual parameters, e.g. haemoglobin content, haematocrit, enzyme contents, and disorders within genes (Pawelski and Maj, 1987).

Until now, vertebrates, including fish, have been in the focus of attention of toxicologists who performed multifaceted studies on toxicity of various metalcontaining compounds and analysed both the pathways along which the compounds penetrated organisms and the duration of exposure to a toxicant.

In this study, dynamics of absorption, distribution and elimination of nickel from carp bodies as well as processes taking place during fish recovery were followed. Both environmental factors and the internal ones affect those processes.

Under natural conditions, there are three pathways along which harmful substances can be taken up into the body: respiration, nutrition, and skin. In the present experiment, the harmful substance was administered via intraperitoneal injection so that a fish received a strictly defined xenobiotic dose, which made it possible to accurately follow changes in chemical and haematological parameters. This experiment concerned two different types of intoxication, brought about in carp by a single intraperitoneal nickel injection. Nickel is an element essential in trace amounts, but harmful when the threshold dose is exceeded. In the present experiment, the fish were exposed to the nickel dose of $60 \mu \mathrm{g} \mathrm{Ni} \cdot \mathrm{kg}^{-1}$ body weight. The dose was selected based on research described by Sobecka (1998) who demonstrated that nickel content of $60 \mu \mathrm{g} \cdot \mathrm{l}^{-1}$ water is the highest nickel concentration that produces no toxic changes in carp. It should be remembered that a half of that content, i.e. $30 \mu \mathrm{g} \mathrm{Ni} \cdot \mathrm{l}^{-1}$, is the allowed nickel content in natural waters assigned to quality class I (Anonymous 1991). Thus the dose used in the experiment doubles the concentration regarded as allowed in a non-polluted aquatic environment.

After nickel injection, the changes were observed until hour 24, as evidenced by the maximum contents attained. Subsequently, the process of nickel elimination from the body began. The elimination was probably associated with increased demand for oxygen because, as reported by Prost (1994), harmful effects of metal salts in fish lead to increased oxygen demand. Consequently, respiratory movements of gill lamellae are accelerated and mucus production is increased. The nickel dose administered was 
very low and did not cause any lethal effect. No fish died naturally during the experiment and all survived until its termination in good condition and the fish remaining in the tanks until termination of the experiment were in good condition.

Following intoxication, the carp were observed to loose much of their vitality as a likely result of shock as well as distribution and accumulation of nickel in the body. Such responses to acute metal ions exposure were also pointed out by Prost (1994). Reduced metabolic activity of the body as a result of metal accumulation in tissues is an underlying cause of reduced metabolic rate of muscle cells (Rice and Harrison, 1978). This can be explained by a decrease in the amount of metabolic energy indispensable for enzymatic transformations that accompany detoxification processes. In the present study, the responses were accompanied by a reduction in the amount of food consumed by the nickel-injected carp.

The changes in the internal organs, observed during necropsy of the nickelexposed carp correspond to descriptions of damages in liver and kidneys inflicted by various concentrations of cadmium and nickel, as described by Sobecka (1998). It could be assumed that, following cadmium intoxication, the metabolic rate would increase in those organs that serve the detoxifying function, the remaining organs restricting their metabolic expenditures. This assumption was borne out by results reported by Heath (1990) who, in an in vitro study of hepatic cells and gills, demonstrated an increased demand for oxygen.

The maximum nickel contents in various carp organs during the experiment varied markedly. The organs examined can be arranged in the following series of decreasing nickel accumulation: skin $>$ liver $>$ kidneys $>$ interior part of the alimentary tracts $>$ gills $>$ mid-posterior part of the alimentary tract $>$ muscles.

The literature shows that the extent of accumulation in and elimination of xenobiotics from various organs vary as well. Sreedevi et al. (1992) who exposed carp for 4 days to nickel dissolved in water in concentration of $20-70 \mathrm{mg} \cdot \mathrm{l}^{-1}$, found the highest nickel accumulation in gills, the lowest accumulation being observed in the liver, muscles, and kidney. In a 4-day-long experiment, Ray et al. (1990) followed the rate of nickel deposition in tissues of walking catfish, Clarias batrachus. They arranged the organs studied in the following series of decreasing nickel contents: kidneys $>$ liver $>$ gills $>$ intestine. Carp bream, Abramis brama caught in the Vistula River showed the highest mercury contents in the liver, intestine, heart, and gills (Kołacz et al. 1996). Svobodova et al. (1997), too, found high contents of lead and mercury in the liver and gonads of the European wels. Windom et al. (1987) suggested that the extent of heavy metal accumulation is related to fish size and weight and the toxicity of chemicals a fish is exposed to.

Each xenobiotic occurs simultaneously in both compartments (central and tissue) as two fractions: protein-bound (inactive) and non-bound (free, active). A substance bound to a serum protein may, however, be subjected to biotransformation and capillary excretion in kidneys. Albumins decide on binding of numerous xenobiotics 
not only in the blood, but also in tissues (Murray, 1999). A similar conclusion was drawn also by Ray et al. (1990) who followed responses of Clarias batrachus to nickel during a 30-day exposure. They observed kidneys and gills to be the most endangered organs.

Many authors showed the amounts of heavy metals accumulated in freshwater and marine fish to vary (Protasowicki 1991, Protasowicki and Chodyniecki 1992, Sharif et al. 1991). According to the literature data, the highest heavy metal contents occur in the liver, the lowest contents being typical of muscles, regardless of the metal absorption pathway (Protasowicki 1991, Hellou et al. 1992). Similar were the results obtained in this study: after intraperitoneal injection, the nickel levels reached peak contents in the liver and kidneys, the lowest contents being recorded in muscles. In both experimental treatments, muscles were observed to accumulate the xenobiotics. Nickel accumulation after a single intraperitoneal injection proceeded until day 3 . Then the metal elimination began until the contents reverted to their initial levels. The detoxification potential and rate are of a key importance for carp used as a food product.

The available literature contains publications that deal only with toxo- and pharmacokinetics of drugs in mammalian organisms (Hirt et al. 2003), while papers discussing toxicokinetic parameters in fish are lacking.

\section{CONCLUSIONS}

1. A single intraperitoneal injection of carp with a sub-lethal nickel nitrate dose produced behavioural responses and damage in gills, liver, and kidneys as well as metabolic and haematopoietic disorders.

2. Once the maximum nickel concentration $\left(\mathrm{C}_{\mathrm{max}}\right)$ had been reached in an organ, the detoxification process began. Nickel elimination from all the organs began as early as 24 hours post injection. During detoxification, nickel was observed to be redistributed among the organs.

3. Nickel elimination rate ranged from 0.003 to $0.008 \mu \mathrm{g} \cdot \mathrm{day}^{-1}$. The biological halflife of nickel ( $\mathrm{t} 1 / 2)$ in various organs ranged within 1.8-10.

4. A long-term effect of sub-lethal nickel intoxication was an about $5 \%$ reduction of the fish body weight, relative to the initial weight.

\section{REFERENCES}

Anonymous, 1991. Rozporządzenie Ministerstwo Ochrony Środowiska Zasobów Naturalnych i Leśnictwa z dn. 5.11.1991 r. w sprawie klasyfikacji wód oraz warunków, jakim powinny odpowiadać ścieki wprowadzane do wód lub ziemi. [Directive of the Minister of Environmental Protection, Natural Resources, and Forestry of 5 November 1991 on water classification and standards for sewage discharged to waters and soils.] 116 (503): 1579-1583. (In Polish.) 
Grabowski T., 2003. Farmakokinetyka i biofarmacja. [Pharmacokinetics and biopharmacy.] http://www.biokinetica.pl/farmakokinetyka.pdf (In Polish.)

Heath A.G., 1990. Water pollution and fish physiology. CRC Press, Boca Raton.

Hellou J., Warren W.G., Payne J.F., Belkhode S., Lobel P., 1992. Heavy metals and other elements in three tissues of cod, Gadus morhua from the Northwest Atlantic. Marine Pollution Bulletin 24 (9): 452-458.

Hirt A. R., Teinfalt M., Dederichs D., van den Hoven R., 2003. The effect of orally administered merbofloxacin on the pharmacokinetics of theophylline. Journal of Veterinary Medicine A 50 (5): 246-256.

Kołacz R., Dobrzański Z., Bodak E., 1996. Bioakumulacja Cd, Pb i Hg w tkankach zwierząt. [Bioaccumulation of $\mathrm{Cd}, \mathrm{Pb}$, and $\mathrm{Hg}$ in animal tissues.] Medycyna Weterynaryjna 52 (11): 686-692. (In Polish.)

Murray R. K., Granner D. K., Mayes P. A., Rodwell V. W., 1999. Biochemia Harpera [Harper's biochemisty.] PWZL, Warszawa. (In Polish.)

Pawelski S., Maj S., 1987. Normy i kliniczna interpretacja badań diagnostycznych w medycynie wewnętrznej. [Standards and clinical interpretation of diagnostic analyses in internal medicine.] PZWL, Warszawa. (In Polish.)

Prost M., 1994. Choroby ryb. [Fish diseases.] PTNW, Lublin. (In Polish.)

Protasowicki M., 1991. Long-term studies on heavy metals in aquatic organisms from the river Odra mouth area. Acta Ichthyologica et Piscatoria 21 (Suppl.): 301-309.

Protasowicki M., Chodyniecki A. 1992. Bioaccumulation of cadmium in some organs of carp, Cyprinus carpio L., in case of per os administration. Archives of Polish Fisheries 1: 61-66.

Ray D., Banerjee K., Chatterjee M., 1990. Bioaccumulation of nickel and vanadium in tissues of the catfish Clarias batrachus. Journal of Inorganic Biochemistry 38: 169-173.

Rice D.W., Harrison F.L., 1978. Copper sensitivity of pacific herring, Clupea harengus pallasi, during its early life history. Fishery Bulletin 76 (2): 347-356.

Sharif A.K.M., Mustafa A.I., Amin M.N., Safiullah S., 1991. Trace element concentrations in tropical marine fish from the Bay of Bengal. Science of the Total Environment 138: 223-234.

Sobecka E., 1998. Wpływ niklu na organizm suma europejskiego Silurus glanis L. [Nickel effects on the European wells, Silurus glanis L.] PhD Thesis, Agricultural University of Szczecin, Poland. (In Polish.)

Sobecka E., 2001. Changes in the iron level in the organs and tissues of wells catfish, (Silurus glanis L.) caused by nickel. Acta Ichthyologica et Piscatoria 31 (2): 127-143.

Sreedevi P., Sivaramakrishna B., Suresh A., Radhakrishnaiah K., 1992. Effect of nickel on some aspects of protein metabolism in the gill and kidney of the freshwater fish, Cyprinus carpio L. Environment Pollutions 77: 59-63.

Svobodova Z., Groch L., Flajshans M., Vykusova B., Machova J., 1997. The effect of longterm therapeutic bath of malachite green on common carp (Cyprinus carpio L.). Acta Veterinaria Brno 66: 111-117.

Windom H., Stein D., Sheldon R., Smith R. Jr., 1987. Comparison of trace metal concentrations in muscle tissue of a benthopelagic fish (Coryphaenoides armatus) from the Atlantic and Pacific oceans. Deep-Sea Research 34 (2): 213-220.

Żmudzki J., Szkoda J., 1996. Narażenie człowieka na pierwiastki toksyczne. Metale i metaloidy - aspekty farmakologiczne, toksykologiczne i środowiskowe. [Human exposure 
to toxic elements. Metals and metalloids-pharmacological, toxicological, and environmental aspects.] Oficyna Wydawnicza Akademii Medycznej w Białymstoku, Białystok No. 220. (In Polish.)

Received: 26 March 2004 Accepted: 8 December 2004 